\title{
Potential Impact of Biotechnology on Adaption of Agriculture to Climate Change: The Case of Drought Tolerant Rice Breeding in Asia
}

\author{
Carl Pray ${ }^{1, *}$, Latha Nagarajan ${ }^{1}$, Luping $\mathrm{Li}^{2}$, Jikun Huang ${ }^{2}$, Ruifa Hu ${ }^{3}$, K.N. Selvaraj ${ }^{4}$, \\ Ora Napasintuwong ${ }^{5}$ and R. Chandra Babu ${ }^{4}$
}

1 Department of Agriculture, Food, and Resource Economics, School of Environmental and Biological Sciences, Rutgers University, 55 Dudley Road, New Brunswick, NJ 08901, USA; E-Mail: nagarajan@aesop.rutgers.edu

2 Center for Chinese Agricultural Policy, Chinese Academy of Sciences, Institute of Geographical Sciences and Natural Resources Research, Jia 11, Datun Road, Anwai, Beijing 100101, China; E-Mails: llp.ccap@igsnrr.ac.cn (L.L.); jkhuang.ccap@igsnrr.ac.cn (J.H.)

Department of Economics and Management, Beijing Institute of Technology, 5 South

Zhongguancun Street, Beijing 100081, China; E-Mail: ruifa@bit.edu.cn

4 Tamil Nadu Agricultural University, Coimbatore, Tamil Nadu 641003, India; E-Mails: knanjundiahs@gmail.com (K.N.S.); chandrarc2000@yahoo.com (R.C.B.)

5 Kasetsart University, Bangkok 10900, Thailand; E-Mail: Orachos.N@ku.ac.th

* Author to whom correspondence should be addressed; E-Mail: pray@aesop.rutgers.edu; Tel.: +1-732-932-9155(219); Fax: +1-732-932-8880.

Received: 2 August 2011; in revised form: 14 September 2011 / Accepted: 19 September 2011 / Published: 30 September 2011

\begin{abstract}
In Asia and Africa the poor tend to live in marginal environments where droughts and floods are frequent. Global warming is expected to increase the frequency of these weather-induced perturbations of crop production. Drought tolerance (DT) has been one of the most difficult traits to improve in genetic crop improvement programs worldwide. Biotechnology provides breeders with a number of new tools that may help to develop more drought tolerant varieties such as marker assisted selection (MAS), molecular breeding (MB), and transgenic plants. This paper assesses some preliminary evidence on the potential impact of biotechnology using data from surveys of the initial DT cultivars developed through one of the main programs in Asia that has been funding DT rice breeding since 1998-The Rockefeller Foundation's Resilient Crops for
\end{abstract}


Water-Limited Environments program in China, India, and Thailand. Yield increases of DT rice varieties are 5 to 10 percent better than conventional varieties or currently grown commercial varieties than it has been in years. So far we only have experiment station evidence that DT varieties yielded better than conventional or improved varieties during moderate drought years (the one drought year during our study period in South India gave inconclusive results) and in severe drought both the DT and the conventional varieties were either not planted or, if planted, did not yield. We find that the governments could help overcome some of the constraints to the spread of DT cultivars by increasing government funding of DT research programs that take advantage of new biotech techniques and new knowledge from genomics. Secondly, public scientists can make breeding lines with DT traits and molecular markers more easily available to the private seed firms so that they can incorporate DT traits into their commercial hybrids particularly for poor areas. Third, governments can subsidize private sector production of DT seed or provide more government money for state extension services to produce DT varieties.

Keywords: drought tolerant rice; climate change; biotechnology; Asia

\section{Introduction}

This paper assesses the impacts of the Rockefeller Foundation's (RF) Drought Tolerant Research program in China, India, and Thailand. It is one of the first major rice research programs on drought-tolerant rice initiated by RF where modern biotechnology has played an important role.

Many of Asia's poorest people live in un-irrigated, drought-prone areas. Significant expansion of irrigation does not seem likely as demand for water by Asia's industrial, housing and service sectors is growing rapidly. Simultaneously, climate change is resulting in increasing temperatures, less rainfall and snow, increasing variability of rainfall and reducing recharge of underground aquifers in many areas of Asia. Rural people in un-irrigated areas have learned to cope with periodic drought through a variety of mechanisms but remain caught in poverty and malnutrition.

Public and private research programs have traditionally neglected drought-prone, un-irrigated lands because of the difficulties and cost of developing improved technologies for these areas as compared to regions with irrigation or more reliable rainfall. As a result, in Asia rice yields in irrigated systems have doubled and tripled over the past 30 years while only modest gains have occurred in rainfed rice systems - even though about $50 \%$ of all rice land is rainfed [1].

Breeders face difficulties in improving drought tolerance in rice varieties because of the rainfed system's heterogeneous and variable environments. Kamoshita and colleagues [2] have developed a classification of three types of drought affecting rice. First, drought can be classified according to the ecosystem in which rice is grown. Upland systems are regularly affected by mild to severe stress conditions continuously throughout the crop period due to shortage of rainfall and a higher evapotranspiration rate. Lowland rice systems often have standing water but can face periodic drought when there is a water deficit. The second kind of drought is primarily based on drought severity during critical stages of crop growth. Drought could occur during the vegetative stage of plant growth or 
during the reproductive stage of the rice crop. The latter type of drought usually has more impact on yields. The third kind of drought is intermittent drought which can be multiple during short dry periods interspersed with rains/irrigation.

Understanding the different drought types helps determine the specific traits required to improve drought resistance [2] as certain traits (deep roots, osmotic adjustments, thick cuticle) within the rice plant help it adapt to mild, or moderate to severe water stress.

Starting in the early 1990s, the Rockefeller Foundation (RF) made substantial investments in drought tolerant rice research in Asia. They supported drought tolerance research for two reasons: (1) in Asia both public and private agricultural research programs have had insufficient funding for research infrastructure and scientific capacity for the development of drought tolerant rice varieties as compared to high-yielding rice varieties for irrigated areas; and (2) rice is Asia's staple food crop and nearly 50 percent of the rice growing area is under rainfed production systems subject to periodic drought.

Recent advances in biotechnology have provided breeders with numerous tools to enhance phenotypic screening, ranging from marker assisted selection (MAS) of key traits to molecular breeding (MB) and genetic engineering [3]. Current research is using these tools to develop enhanced drought tolerance in rice cultivars in China, India and Thailand [4]. In this context, conventional breeding techniques have been combined with MAS, and several drought tolerant rice varieties were released for commercial cultivation in these countries.

Economists predict high rates of return on investments in drought tolerant rice research and adoption of these varieties [5]. Kostandini and colleagues [5] argue that transgenic drought tolerant rice research would generate sizeable profits for technology producers (both private and public), consumers and the adoption of such cultivars would generate major benefits to farmers [6] in the affected environments in India. This paper discusses impacts of adopting drought tolerance (DT) cultivars in farmers' fields in terms of yield, water use and quality attributes in China, India and Thailand. Section 2 describes the DT rice research program funded by RF in China, India and Thailand and discusses new breeding technologies and approaches that led to the development of DT cultivars. Section 3 provides a preliminary look at empirical evidence on the impact of adoption on yield, water use efficiency and quality attributes. Section 4 discusses the question why DT varieties have spread so slowly. The final section brings together lessons learned from these countries in the diffusion and adoption of DT varieties and from the RF research initiative on DT rice in Asia.

\section{Biotechnology Research on Drought Tolerant Rice in Asia}

In 1998, The Rockefeller Foundation (RF) began supporting a multi-year, multi-country research and technology transfer program focusing on the development of drought-tolerant rice varieties in China, India and Thailand. The Foundation also began to support the International Rice Research Institute (IRRI) to focus more research and development efforts on this issue. Complementary funding to this effort came from the British government's support to participatory breeding for drought tolerance and other important traits in Western and Eastern India and United States Agency for International Development (USAID)'s Agricultural Biotechnology Support Project II (ABSP) program to develop drought tolerant varieties for India and Bangladesh through genetic engineering. Currently, 
conventional breeding techniques remain the main technology used by plant breeders to improve drought tolerance and most other traits in new rice varieties in India and Thailand and for hybrids in China.

Applying biotechnology systematically to rice research in Asia began in 1985 with The Rockefeller Foundation's International Program on Rice Biotechnology. During the program's first five to seven years, it funded leading public- and private-sector biotechnology research programs worldwide to delineate the rice genome, to understand the molecular basis of rice resistance to biotic and abiotic stresses and to develop tools for rice biotechnology research and engineering. This basic research was then spread to the developing world through RF funding for new PhDs, post-doc opportunities for developing country scientists in advanced research labs and physical infrastructure to establish biotechnology research labs in universities and research institutions. The Foundation also funded rice biotech research projects and networking in developing countries [7,8].

Drought tolerance was one of The Rockefeller Foundation rice biotechnology program's goals. Scientists from India, Thailand and China earned PhDs and conducted post-doctoral research on drought tolerance using the new findings on the rice genome and new techniques such as molecular markers. For example, in India scientists from Tamil Nadu Agricultural University (TNAU) developed molecular markers for drought during their post-doctoral research at Texas Tech University (1994-1996). They returned to India and began breeding for drought tolerance using these markers and also continued their research to develop new markers to better understand drought tolerance. The RF supported this research from 1997 to 2006, and in 2006, when RF support began to decline; TNAU was able to garner funding from other organizations [9] to continue. From 1994 to 2010, The Rockefeller Foundation contributed \$1 million to TNAU's drought tolerance research efforts [10].

Elsewhere in India and in China and Thailand, scientists received similar support from the RF to undergo PhD training in leading biotech institutes of Australia, US, Europe and elsewhere. This was followed by research support when they returned to their home countries. In the last phase from 1997 to 2006, the RF funded the construction of "rain-out" shelters on research stations that precisely control the amount of water rice receives from rainfall, irrigation, seepage from other fields and groundwater. In addition to support for country programs, RF supported research at IRRI on drought tolerance and collaborations between IRRI and Asian national scientists through seminars, training, joint research projects and the provision of germplasm. The results of these efforts are now reaching farmers' fields.

Other than these RF funded programs, only limited research on drought tolerant rice was conducted in Asia in the mid-1990s. The Indian Council of Agricultural Research (ICAR) has maintained a research station on upland rice in Hazaribagh, Bihar, for many years but few varieties have been developed and spread to farmers. The Chinese Academy of Agricultural Sciences (CAAS) and some provincial academies of agricultural science have developed programs on drought tolerance in Yunnan and in northern China. The Yunnan program has developed varieties and hybrids for their province.

The Chinese DT rice program in Shanghai exemplifies large-scale development of DT rice hybrids for commercialization. With the establishment of a science-based field screening facility at Shanghai Agro-biological Gene Center in 2001, nearly \# 800 DT rice germplasm lines were evaluated under water-controlled conditions. Of these 46 lines showed high-level drought tolerance for further selection and improvement. 15 DT lines were selected from this collection (of 46 lines) and were used 
as donor parents for the molecular breeding program to identify necessary molecular markers for DT. Several drought-tolerant hybrids have been identified and developed since 2003. In 2007, the first DT rice hybrid, Hanyou-3, was approved for commercial release in Guangxi province.

The Indian private sector began investing in rice research about twenty years ago, building on the successes of the Chinese government's hybrid research programs and IRRI's long-term hybrid rice research program. All of these private sector research programs focused initially on finding the right combination of lines to give high yields, developing good grain quality and reducing costs of seed production. Drought tolerance was not a major program goal. However, somewhat surprisingly, in India early hybrids were accepted in the low land rice areas of Eastern India, areas which did not have good irrigation and thus could not use modern high-yielding rice varieties. Hybrids in these areas have shown some resistance to some types of drought, especially mild to moderate in nature. As a result of the spread of hybrids to these areas, private companies are now coming to Indian State Universities for access to drought tolerant lines they can include in their research programs (Interviews with Rasi Seeds (I) Ltd and [10]).

A few research projects in China and India are attempting to develop transgenic rice with drought tolerance. In 2005, the Huazhong Agricultural University (Wuhan, China) began testing a number of transgenic lines for drought tolerance. Since early 2000, major public institutions such as Tamil Nadu Agricultural University (TNAU), the University of Agricultural Sciences in Bangalore and a few public rice research institutions have developed and are testing transgenic rice lines. Private Indian firms such as Mahyco and Barwale Foundation and multi-national firms such as Bayer Crop Sciences, Dupont-Pioneer, Syngenta and Advanta have made investments in developing certain stress tolerant (both biotic and abiotic) transgenic lines of rice[11].

\section{Approval and Spread of DT Rice Varieties in Asia}

Investment in developing DT cultivars, both through conventional and biotech-based breeding is beginning to pay off in the development of new plant varieties and in the creation of new knowledge about how rice responds to drought. In some areas in India, China and Thailand, farmers began growing drought-tolerant varieties developed using conventional breeding (see Table 1), while in other places biotech-based varieties are being tested. In 2009, the first variety produced by molecular breeding was introduced in the eastern upland areas of India.

In addition to drought tolerance, other improved traits are also found in the varieties being commercialized:

- Short duration (which provides some drought tolerance)

- High quality grain

- Improved yields in non-drought conditions

- Disease and pest resistance (Thai RD varieties and Chinese Hanyou 2)

- Decreased levels of methane emission, thus more environmentally friendly (Aerobic rice in South India). 
Table 1. Drought tolerance (DT) Varieties/Hybrids Approved and Seed distribution.

\begin{tabular}{|c|c|c|c|c|}
\hline Region & $\begin{array}{c}\text { Drought tolerant } \\
\text { varieties/hybrids * }\end{array}$ & $\begin{array}{c}\text { Year of } \\
\text { commercial } \\
\text { approval }\end{array}$ & $\begin{array}{l}\text { Quantity of seed } \\
\text { distributed }\end{array}$ & $\begin{array}{c}\text { Institutions that distribute } \\
\text { seed }\end{array}$ \\
\hline \multirow[t]{3}{*}{ China } & Hanyou 3 & 2007 & 1.5 mt (Hanyou 3) 2009 & Zhejiang Yuhui \\
\hline & \multirow{2}{*}{ Hanyou 2} & \multirow{2}{*}{2010} & 5 mt (Hanyou-3) 2010 & Agro-technology Company \\
\hline & & & $4 \mathrm{mt}$ (Hanyou-2) 2010 & (ZJYH), Zhejiang. \\
\hline \multirow[t]{6}{*}{ Thailand } & \multirow{4}{*}{ RD 12 (Glutinous) } & \multirow{4}{*}{2007} & $2 \mathrm{mt} 2003-08$ & $\begin{array}{l}\text { Research trials, } \\
\text { demonstrations. }\end{array}$ \\
\hline & & & \multirow{2}{*}{$6 \mathrm{mt} 2009$} & Rice Dept. sales in \\
\hline & & & & 2009 and 2010 \\
\hline & & & $10 \mathrm{mt} 2010$ & \\
\hline & RD 33 & & & \\
\hline & $\begin{array}{l}\text { (non-glutinous, } \\
\text { Jasmine) }\end{array}$ & 2007 & $62 \mathrm{mt} 2009$ & Rice Dept. sales in 2009 \\
\hline \multirow{5}{*}{$\begin{array}{l}\text { Eastern } \\
\text { India }\end{array}$} & Ashoka 200F & \multirow{2}{*}{2005} & & \multirow{4}{*}{$\begin{array}{c}\text { Research trials, } \\
\text { Gramin Vikas Trust } \\
\text { and other NGOs }\end{array}$} \\
\hline & (BVD-109) & & & \\
\hline & Ashoka 228 & \multirow{2}{*}{2005} & \multirow{2}{*}{$250 \mathrm{mt} 2007$} & \\
\hline & (BVD-110) & & & \\
\hline & PY84 (BVK 111) ** & 2009 & $255 \mathrm{mt} 2008$ & $\begin{array}{l}\text { Government Extension } \\
\text { System }\end{array}$ \\
\hline \multirow{7}{*}{$\begin{array}{l}\text { South } \\
\text { India- } \\
\text { Tamil } \\
\text { Nadu }\end{array}$} & PMK1 & \multirow{4}{*}{1985} & \multirow{4}{*}{$13 \mathrm{mt}$} & \multirow{7}{*}{$\begin{array}{l}\text { TNAU Research Station, } \\
\text { Government Extension } \\
\text { System }\end{array}$} \\
\hline & (drought-tolerance) & & & \\
\hline & PMK2 & & & \\
\hline & (semi-dry \& dry) & & & \\
\hline & PMK3 (grain quality) & 1994 & $23 \mathrm{mt}$ & \\
\hline & Anna R 4 & 2003 & $16 \mathrm{mt}$ & \\
\hline & (everything together) & 2009 & $6 \mathrm{mt}$ & \\
\hline \multirow{4}{*}{$\begin{array}{l}\text { Karnataka } \\
\text { (Aerobic } \\
\text { Rice) }\end{array}$} & MAS $946-1 * *$ & 2007 & \multirow{4}{*}{ Not available } & \multirow{4}{*}{$\begin{array}{l}\text { Still under on-farm trials of } \\
\text { University of } \\
\text { Agric.Sciences (UAS), } \\
\text { Bangalore }\end{array}$} \\
\hline & MAS $26 * *$ & 2008 & & \\
\hline & ARB6(Anagha) & 2009 & & \\
\hline & & & & \\
\hline
\end{tabular}

Source: Authors. Ashoka varieties started to spread from 2002 onwards- way before the official release in 2005; the quantity of seeds supplied refers to Jharkhand state only in eastern India. RF did support DT rice research and development in eastern U.P and Chhattisgarh, but so far DT varieties were approved are distributed eastern state of Jharkhand and Orissa. * Only China has DT rice hybrid varieties; in India and Thailand the DT cultivars are openpollinated varieties. ** Varieties developed through DNA-marker assisted selection (MAS) methods.

Since the late 1990s, two drought-tolerant hybrids have been identified and developed in China. In 2007, the first DT rice hybrid, Hanyou-3, was approved for commercial release in southern China, specifically in Guangxi, Shanghai and Zhejiang provinces with the Shanghai Biodiversity Center producing about $10 \mathrm{mt}$ of hybrid seeds.. In 2007, Jinghua Co. in Zhejiang province was the first commercial firm to multiply seeds of Hanyou-3. They produced enough to cover about $500 \mathrm{mu}$ (33 hectares). Also in 2007, Zhejiang Yuhui Agro-technology Company (ZJYH), located in Hangzhou, Zhejiang province, produced seeds of Hanyou-3 hybrids for sale in Guangxi and Zhejiang provinces, and from 2010 onwards, has produced and sold Hanyou 2, a new hybrid commercially released in 2010. 
In Thailand, two major DT varieties, RD 12 and RD 33, developed by RF-funded research at the Nongkhai Rice Research Center, were released in 2007. RD 12 is glutinous rice, targeted for the upper north-eastern region where intermittent and late-season drought greatly reduces rice productivity. $\mathrm{RD} 33$ is a non-glutinous, fine, Jasmine-type of DT rice suitable for all of Thailand's major, rice-growing regions [12]. Since its release, $\mathrm{RD} 12$ adoption has been significant, especially in Nongkhai province. Prior to its release, about 80 farmers received free RD 12 samples directly from the research station from 2003-2007. In 2008 after their official release the rice research center at NongKhai began selling RD 12 seeds and nearly 18 tons have been sold since then. Currently, RD 12 and RD 33 seeds are multiplied and sold through government agriculture departments (see Table 2). In addition, farmer-to-farmer seed exchanges and use of farmer-saved seed of RD 12 is also prevalent in Nongkhai province.

In eastern India, two varieties, Ashoka 228(BVD-109) and Ashoka 220 F (BVD-110), were developed with funding from the UK Department of International Development (DFID) and its Plant Sciences Research Program and with some support from the RF (2005-2009) through a partnership between the NGO Grameen Vikas Trust (GVT) and the University of Bangor University at Bangor, U.K. The government of India officially released both varieties in 2005 but farmers have cultivated both since 2002 through GVT's on-farm and adaptive research trials. GVT first disseminated the DT rice varieties in 2002 in the districts of Ranchi and Hazaribagh (Jharkhand State) as these two districts have the maximum area under upland rice cultivation. However, since the introduction of Ashoka varieties through trials, state-sponsored schemes and NGOs have extended the use of DT cultivars to other parts of the state. From the farm level impact surveys on Ashoka varieties conducted by the DFID, The Research Into Use (DFID-RIU) team among the villages in Jharkhand, it was evident that nearly 95\% of the farmers who tried Ashoka varieties, supplied through from 2003-2008, have continued growing Ashoka varieties, despite little or no subsequent outside interventions in their villages [13]. Yet, non-availability of good quality seeds in subsequent seasons resulted in dis-adoption in many areas.

To enhance delivery of farmer-preferred DT rice cultivars in eastern India, the RF funded in 2005 the establishment of three seed-processing units (two units in Jharkhand and one in Orissa) to multiply upland, DT varieties for distribution to farmers. The seed processing facility also extended their services to other seed agencies and seed growers on commercial basis at all locations to meet the cost of running these units. Since 2006 onwards, the availability of Ashoka seed varieties has improved greatly, from 17 tons to the 150-200 tons sufficient to cover nearly 3000 hectares in eastern India by the end of 2007. 
Table 2. Yields of DT rice in China, India and Thailand.

\begin{tabular}{|c|c|c|c|c|c|}
\hline Country name & DT Rice & Mean Yield & Non-DT rice & Mean Yield & Remarks \\
\hline \multicolumn{6}{|l|}{ China (Kg/Ha) } \\
\hline \multirow[t]{2}{*}{2005 National trials } & Hanyou 3 & 6254 & Zhong Han No.3 & 4799 & \multirow{2}{*}{$\begin{array}{c}\text { Trials under drought conditions in a } \\
\text { number of provinces that represent } \\
\text { drought prone in China }\end{array}$} \\
\hline & Hanyou 2 & 6153 & Shan You 63 & 5014 & \\
\hline \multirow{4}{*}{$\begin{array}{c}2006 \text { Provincial trials } \\
\text { (Guangxi) }\end{array}$} & Hanyou 3 & 6860 & Shan You 63 & 6034 & \multirow{4}{*}{ Normal year testing } \\
\hline & (late season) & & & & \\
\hline & $\begin{array}{c}\text { Hanyou } 3 \\
\text { (early season) }\end{array}$ & 7077 & Shan You 63 & 6399 & \\
\hline & Hanyou 3 (single season) & 6916 & Shan You 63 & 5972 & \\
\hline \multirow{5}{*}{$\begin{array}{c}2009 \text { farmer field } \\
\text { experiments }\end{array}$} & Hanyou 3 & 6147(895) & Others & $5843(1040)$ & \multirow{5}{*}{$\begin{array}{l}\text { Normal year trials; numbers in } \\
\text { parenthesis indicate yield } \\
\text { variability i.e., deviation from } \\
\text { mean } \\
\end{array}$} \\
\hline & & Guangxi \& Zhejiang & & Guangxi \& Zhejiang & \\
\hline & & 6104 (994)-Guangxi & & 5635(1075)-Guangxi & \\
\hline & & & & & \\
\hline & & 6265 (538)-Zhejiang & & 6422 (660)-Zhejiang & \\
\hline \multicolumn{6}{|l|}{ Thailand (Kg/Ha) } \\
\hline Wet season & & & & & Hanhg Yi71 is an old, DT \\
\hline \multirow[t]{3}{*}{ Non-Irrigated conditions } & RD 12 & 2032 & RD10 & 2025 & cultivar grown in upper terrain \\
\hline & & & & & like $\mathrm{RD} 12 . \mathrm{RD} 10$ is non-DT \\
\hline & Hanhg Yi71 & 1885 & & & grown in lower terrain conditions. \\
\hline
\end{tabular}


Table 2. Cont.

\begin{tabular}{|c|c|c|c|c|c|}
\hline Country name & DT Rice & Mean Yield & Non-DT rice & Mean Yield & Remarks \\
\hline \multicolumn{6}{|l|}{ India-Tamil Nadu (Kg/Ha) } \\
\hline \multirow[t]{2}{*}{$\begin{array}{l}\text { Normal year } \\
\text { (Rainfed ) }\end{array}$} & PMK 3 & 2850 & Mattai & \multirow[b]{2}{*}{1200} & $\begin{array}{l}\text { Results from research station } \\
\text { trials of TNAU; Popular HYVs }\end{array}$ \\
\hline & Anna R 4 & 3882 & & & $\begin{array}{l}\text { include ADT 36, ADT 45, IR } \\
\text { 36- average yield 2000-3250 } \\
\text { under semi-dry conditions }\end{array}$ \\
\hline Drought year-2009 & Anna R 4 & 1933(795) & Mattai (Land race) & $1890(345)$ & On-farm trials conducted \\
\hline (Early drought conditions) & PMK3 & 2173(670) & ADT36(HYV) & 2328(350) & $\begin{array}{l}\text { among } 50 \text { farmers in } \\
\text { Sivaganga district; numbers in } \\
\text { parenthesis indicate yield } \\
\text { variability i.e., deviation from } \\
\text { mean }\end{array}$ \\
\hline \multicolumn{6}{|l|}{ India-Jharkhand (Kg/Ha) } \\
\hline & Ashoka $200 \mathrm{~F}$ & 1768 & BG102 & 1340 & \multirow{3}{*}{$\begin{array}{l}\text { Upland conditions during } \\
\text { normal years }\end{array}$} \\
\hline & Ashoka 228 & 1808 & Kalinga 3 & 1390 & \\
\hline & PY 84(BVK 111) & 2196 & Vandana & 1747 & \\
\hline
\end{tabular}

Source: Calculated from the Farm field trials and surveys in China, Thailand and India. Jharkhand data on Ashoka varieties and PY 84 was provided by Virk and Witcombe,

University of Bangor, Bangor, UK in August, 2009. 
By 2009, the first variety was approved in East India that breeders consider the result of molecular assisted breeding (MAB). PY 84, officially named BVK 111 when released in 2009 in Jharkhand state, was developed through collaboration between GVT and the University of Bangor with some help from Birsa Agricultural University.

Since 1985, Tamil Nadu Agricultural University (TNAU) has developed and released four DT rice varieties (PMK1, PMK2, PMK3 and Anna 4 R) in southern India and continues to work on developing better varieties with improved attributes through both conventional and MAS breeding. DT cultivars have been introduced to farmers through various on-farm trials in two major rainfed districts of Ramnad and Sivaganga, now covering nearly 400 hectares (1500 households). Although the government extension system also produces seeds of DT varieties on their seed farms from time to time for very limited distribution, TNAU's regional rice research stations at Paramakudi and Madurai are the only major sources for DT seed for distribution in Tamil Nadu.

In another south Indian state of Karnataka, scientists have bred DT rice varieties suitable for aerated soil environments (non-puddled rice fields). These varieties can withstand long drought periods as irrigation for aerobic rice is provided once in 5-7 days, especially during the critical stages of the direct seeded crops. This type of cultivation reduces water use by about 60 percent and also reduces methane emission substantially since rice crops are not produced in paddies, the major source of methane. In 2007, University of Agricultural Sciences (UAS), Bangalore developed a new mid-early, medium-fine grain, high-yielding variety, MAS 946-1, using DNA Marker Assisted Selection. This was followed by another varietal release, MAS 26, in 2008. Both of these varieties yielded 5.5 to 6 tons/hectare: 42\% higher than the check varieties (Rasi and Bapatla (BPT) varieties) and 60\% higher than traditional cultivars under experiment station conditions. They are suitable for the three southern dry districts of Karnataka.

One other aerobic rice, ARB6 (named Anagha), was also released for commercial cultivation by UAS, Bangalore in 2009, using conventional breeding methods with farmers' participatory varietal selection. ARB6 is capable of yielding 1.9 t/ha under complete rainfed conditions and with sufficient irrigation can achieve a maximum yield of 6.9 tons/hectare. Grains of ARB6 are of medium-slender type with good cooking quality. Several private-sector firms (Avesthagen, Spriha BioSciences, Rasi seeds, Mahyco and Ajith seeds) have sought access to the technology for commercialization [14].

\section{Impact of DT Rice in Asia}

A number of studies have reported on impacts of DT varieties in experiments run by scientists, but no one has examined impacts of these varieties in farmer-managed fields. As a result there is no clear evidence of how results from experiment stations will translate into benefits (or losses) in farmers' fields. One of this study's major contributions is that we conducted a series of field-based, farm-level socio-economic surveys in the DT rice adoption countries during 2008-2010 to understand impacts of these cultivars on farmers. We conducted these studies in regions where DT rice varieties have been approved for cultivation by governments, although in China and south India very little commercial seed had yet reached farmers.

Different methodologies were used in different regions depending on whether farmers were already growing DT cultivars fairly extensively (Thailand and East India) or whether cultivars were still not 
commercially available to farmers (China and South India). In China and South India, we used experimental design techniques in which randomly chosen farmers were given DT and non-DT hybrids along with crop management information to ensure we did not have selection bias and would be able to correctly estimate the contribution of DT to yield and other parameters. In Thailand and East India, we selected villages where DT varieties were being used by farmers and then surveyed farmers (300 of them) who were chosen by a random sampling process within those villages, controlling for selection bias by using econometric techniques.

The results of our first year surveys in China, Thailand, and South India are reported in Table 2 along with some data from controlled field trials. We are currently analyzing survey data for the second year in those countries. Our survey in East India is underway (February 2011) and so we have reported results from a previous survey of a small sample of farmers conducted in Jharkhand during the year 2007 by University of Bangor.

Two provinces in southern China were selected for the study: One village in Yiwu County in Zhejiang province and eight villages in Guangxi province. Yiwu is a major industrial area with a rapidly growing non-agricultural water demand. Guangxi province is one of southwest China's main rice growing areas and is often drought prone. A random sample of 160 farm households was given Hanyou 3 (HY3) to compare productivity, cost-savings and water use between the cultivars in different seasons across the provinces. Preliminary results show that average yields of DT hybrids were significantly higher than non-DT (NDT) cultivars. On average, DT yielded $6135 \mathrm{~kg} / \mathrm{ha}$ as compared to $5760 \mathrm{~kg} / \mathrm{ha}$ for NDT. Recent data from our field experiments conducted on farmers' fields in Guangxi and Zhejiang in 2009 also show that yield variability (i.e., deviation from mean yield levels) in DT is less (885 Kg/ha) as compared to NDT cultivars (1020 Kg/ha) (see Table 2).

Regression estimates on the effect of DT adoption by farm households on yield levels indicate that DT rice enhanced farm households' total rice production levels by 28-30 kilograms per 0.07 hectares, a 7.8\% yield increase as compared to non-DT cultivars [15]. The farmer survey indicated that sample farmers gave less (2 times) irrigation to DT varieties as compared to NDT cultivars, thus saving 33\% of water over NDT especially in Guangxi province $[15,16]$. These results imply that DT cultivar HY3 is water-saving, high-yielding type with less yield variation. As there was no drought in the year of our experimental trials, one cannot generalize the potential yield advantage of DT over NDT in drought years. However, the experimental trials did show that the DT cultivar increased yield (even under normal conditions) with less irrigation than NDT.

In Thailand, research sites were selected to study adoption behavior of 244 farmers growing RD12 and to compare economic efficiency of RD 12 to the main cultivar, Hang Yi71, in NongKhai province. Hang Yi71 was preferred by farmers and traditionally grown in the upper terrain regions of north eastern Thailand. The Rice Department of Thailand through its breeding efforts released RD 12, another glutinous variety, suitable for upper terrain conditions like Hang Yi71, but with such improved attributes as better cooking quality, earlier maturity and disease (blast) resistance. Our farm-level surveys in NongKhai province (2009) reveal that Hang Yi71 is now being replaced by RD 12 in the upper terrain.

Further analysis on efficiency of RD12 over Hang Yi71 has shown that under direct seeding conditions, with limited or no external inputs such as pesticides, RD12 performs better (nearly 200 kg/ha higher) than Hang Yi71. Most DT growers use RD 12 for home consumption because of 
cooking quality such as aroma, but this cooking attribute is not yet reflected in market prices as traders fix rice prices based on physical appearance of the unmilled grain and Hang Yi and RD12 look the same until cooked. Currently, government extension programs disseminate RD12 seeds although farmer to farmer seed exchanges and use of farmer saved seed are also common in RD 12 growing regions of NongKhai province.

Farm-level studies conducted in Eastern India by Virk and Witcombe between 2002 and 2004 on adoption of two major DT cultivars, Ashoka 200F(BVD-109) and Ashoka 228(BVD-110) reveal that most farmers perceive that the new Ashoka varieties are higher yielding in grain and fodder, earlier to mature and have better grain quality as compared with local varieties. They also received a higher market price because the varieties' long and slender grains are preferred in this region. The price advantage averaged 12\% for both varieties in Eastern India (Rs 6.28 per kg for the Ashoka varieties and Rs 5.62 per kg for the local variety) [17]. After the severe drought of 2002, most farmers reported that the new varieties had better drought tolerance and weed suppression [17].

A DFID-RIU case study (2010) assessing impacts of two DT rice varieties (Ashoka $200 \mathrm{~F}$ and 228) also confirmed that introducing these cultivars in the upland rice system of eastern India has significantly improved yield levels and grain self-sufficiency of farm households, especially during lean months[18]. This also has decreased grain-related expenditures within adopting households, freeing up funds for other uses such as children's education and improving the overall welfare of the farm household in rainfed environments.

In the southern districts of Tamil Nadu, droughts are frequent (once in 3 years), and this had severely depressed rice production in terms of declining rice acreage and productivity levels over the last three decades. Farmers in these districts grow rice under two systems: dry-rainfed conditions and semi-dry conditions with a few supplementary irrigations (maximum of 2 to 3 times, if available) during critical stages of crop growth [19]. Under dry-rainfed conditions, farmers grow mostly land races such as Mattai, a highly drought tolerant cultivar with good cooking quality, aroma and taste but with poor yield and input efficiency (low response to fertilizers/nutrients), longer duration and poor milling quality as compared to popular high-yielding varieties (HYVs) currently found in the market. HYVs are mainly grown under semi-dry conditions and are preferred for their short duration, selling qualities such as slender and medium sized grains, as well as higher input efficiency and yields. Yet, during years of low rainfall (moderate to severe drought years), the probability of failure of HYVs is very high compared to land races. To address this situation, TNAU released a series of DT varieties from the early 1980s (see Table 1) to suit the agro-ecologies and cropping systems of Ramnad and Sivaganga districts.

All the released DT varieties have yield advantages, especially under moderate to severe drought conditions on experiment stations, are suitable for dry and semi-dry systems and also have good cooking and milling qualities. In TNAU's field-level experimental trials conducted in 2008, DT yields were almost three times higher than land races, almost equal to existing HYVs and also yielded better under drought conditions (Table 2) when most HYVs failed to yield. In a small sample of 23 farmers (2008-09 season) during a non-drought season, DT rice adopters on average realized $2926 \mathrm{~kg} / \mathrm{ha}$, 8 percent higher than the HYVs [20].

Our farm level surveys conducted during the early drought in Sivaganga district in 2009 revealed a marginal increase in yields of improved DT varieties (PMK 3 and Anna 4) over existing land race 
Mattai. Part of the reason for the limited benefit was that the early drought caused poor germination of both the DT varieties and Mattai. In this situation, farmers normally re-sow seed. They had seeds of the traditional variety (Mattai) at their homes and could resow. However, improved DT seeds had come from the research station and farmers could not get more seeds of PMK 3 and Anna 4 to resow. As a result, yield data compare drought stressed DT varieties with Mattai that had been resown, and still there was little difference in yields. The high-yielding variety (HYV) ADT 36 was not affected by the early drought prevailing in 2009 as HYVs are usually sown 3 to 4 weeks after DT varieties to take advantage of monsoon rains.

In summary, our field-based research studies on the impact of DT rice cultivars in Asia suggest:

- DT cultivars in China, India and Thailand usually yielded more than existing cultivars under normal or high rainfall conditions. Observation from experiment station fields by scientists late in 2009 suggests that DT varieties will yield much more under drought conditions, but as yet we do not have data of large yield gains from farmers' fields under drought conditions.

- Water use efficiency as measured by yield per unit of irrigation in China and Southern India was greater than in non DT varieties. In rainfed conditions of southern and eastern India, the crop duration was much shorter with DT varieties than HYVs or land races, also suggesting more effective use of soil moisture.

- The consumption preference for DT cultivars also was high in most places because of improved cooking attributes such as aroma and quality (Thailand), fineness and color (India).

\section{Constraints in DT Rice Research and Diffusion}

Despite the development of some varieties and hybrids with potential to improve yields in good years and provide some protection against drought, these early DT rice varieties do not appear to be spreading rapidly. Several reasons could account for the slow spread: (1) breeders may not have developed varieties that actually meet farmer needs; (2) the regulatory system may constrain the spread of DT varieties; and (3) the seed production and distribution system may not be in place to provide enough DT seed consistently to farmers.

\subsection{Research}

For many years, plant breeders have recognized the potential benefits of drought tolerance and have undertaken research to identify and incorporate drought tolerance into high-yielding varieties. However, support for this research has been limited. Poor farmers in drought-prone areas have limited money to buy improved seed or complementary inputs and so the private sector has had little incentive to develop varieties or distribute seed of drought-tolerant varieties. Thus, the development of drought-tolerant varieties has been left to government research. However, the public sector has also generally focused research resources on areas with irrigation or secure rainfall as it is easier to develop varieties for these areas and farmers in these areas are wealthier and have more political clout. Fan and Hazel [21] have argued that because so little research has been put into dry areas, social and economic benefits from this research may be very high. It has been found that the allocation of rice research resources to rainfed areas in India is disproportionately small relative to the potential contribution of 
these areas in making efficiency and equity impacts [1]. The share of even this limited amount of resources targeted to address abiotic constraints such as drought and submergence is less than $10 \%$ [1]. In recent years, drought tolerance has received more attention from governments and foreign donors concerned about global warming and poor people, many living in drought prone regions[22].

Even long-term government research programs have produced few varieties for drought tolerance and often the addition of drought tolerance has come at the expense of another valuable trait such as yield or grain quality. Table 2, above, shows only a limited number of DT varieties have been approved. Further, a steady supply of new DT varieties has not been available as in major irrigated areas of India and China [1], suggesting varieties adapted to local conditions will also be less readily available.

So far, only one DT variety has been developed using molecular breeding (BVK 111, East India). Two other aerobic rice varieties have been released in Karnataka, South India during 2008-2009 developed through marker assisted selection methods. Developing knowledge about the location of drought tolerant traits on the rice genome and transferring these key genes or gene groups into a cultivar attractive to farmers has taken a long time. Perhaps if governments and foundations had invested more money in DT rice research, the process could perhaps have been accelerated.

As mentioned above, limited research on transgenic drought tolerant rice has been conducted in all three countries. As with convention breeding, most research on transgenic rice does not focus on drought tolerance but on other traits such as insect resistance and herbicide tolerance. After more than 20 years of development, no GM rice is sold commercially in any country of the world. This fact alone has discouraged scientists (from research) and has made governments and the private sector reluctant to invest.

\subsection{Regulations}

In all countries under consideration here, new varieties or hybrids must be registered with the government before sold commercially. Typically, tested for several seasons, they must be proven superior to a local check variety in terms of yield/ha or some other trait like grain quality or stress resistance. Researchers face several complex questions in testing drought tolerant varieties: (1) How to test varieties under conditions similar to those farmers face during droughts (plant breeders also face this problem when selecting drought tolerant lines from segregating material); (2) What kind of drought should be tested for (no water, severe drought, mild drought, drought during planting season, mid-season, flowering, etc.)?; and (3) What check varieties should be used?

In China when the first varieties were developed in 2000, a national testing system for drought tolerance was also developed. However, there were not enough varieties to warrant a national system, so in 2005 the system was discontinued. Thus, the first hybrid developed in China, Hanyou 3, could only be approved at the provincial level and at first it was only approved in Shanghai where it was developed and in Guangxi which had more drought problems than most of the country. It has gradually been approved in four more provinces. A hybrid developed at the same time, Hanyou 2, was not officially released nationally before it passed the regular (non-drought) national testing system in 2010. It had higher yields in varietal tests than check varieties and experiment station data also showed drought tolerance. In total the national testing system required five years since the Shanghai center had completed the development and testing of these varieties by 2005. 
The Ashoka varieties of Eastern India were developed by Gramin Vikas Trust (GVT) an NGO, University of Bangor with assistance from International Rice Research Institute (IRRI) and the Central Rice Research Institute (CRRI). They were first tested in the All-India Coordinated Trials in 1999. Initially, GVT was unsuccessful in getting approval for these varieties because of no provision in Indian seed regulations for NGOs to release new varieties. Eventually, GVT collaborated with Birsa Agricultural University, and the varieties were approved as BAU varieties for state-level release in Eastern India 2005.

In South India scientists seem to have fewer problems achieving state level approval for their drought tolerant varieties. But the process of popularizing and distributing DT varieties through the existing extension program is causing major difficulties in dissemination (see the next section of this paper).

GMOs have to go through separate biosafety regulatory systems in all of these countries. China is the only country in which any GM rice variety has passed through biosafety regulations. Pest resistant and disease resistant rice cultivars have been approved for production but will not be in farmers fields for several more years. No GM drought resistant rice has made much progress in the biosafety regulatory process in China as yet. In India only GM cotton has been approved and Thailand has not approved any GM crop for commercial use. It is unclear when GM food crops will be approved in these countries.

Cultivars developed by marker aided selection are not genetically engineered. They do not need to go through the GMO regulatory system but must pass variety registration tests just as other new cultivars. The first DT varieties developed using molecular breeding, PY 84 (BVK 111) in Eastern India was approved in 2009.

\subsection{Seed Production and Distribution}

Varieties developed by research programs and passing the government approval process still face many difficulties before reaching the farmers if the seed distribution system does not invest in seed production and marketing. Seed can be produced and distributed to farmers through four institutions: (1) farmers themselves; (2) private seed companies; (3) government seed companies or extension services; and (4) NGOs. Our case studies show that the overall effect on production was modest (see Table 2). The most was the 280 metric tons of the Ashoka varieties in Eastern India in 2008.

Private firms have mainly been interested in hybrid rice breeding, production and marketing although some small firms produce rice varieties in Andhra Pradesh and a few other areas of India [14]. China is the only place where hybrid drought tolerant cultivars have been released and some small companies are multiplying them. But, hybrid seed production in China has been limited because problems with seed production technology have so far meant high costs of seed production. With increased yields of new hybrids at only 5 to 10 percent (see Table 2), high-cost hybrid seed would have a very limited market. Private firms have not shown much interest in DT rice seed production and distribution outside of China although private firms in India have begun talks with government breeders about using DT lines in their hybrid rice breeder programs.

In East India and Thailand, farmers can produce, save and exchange seed of improved varieties because the seeds are not hybrids. Evidence indicates DT varieties are slowly spreading in this way. 
Thailand's government Rice Department has decided to regularly produce and distribute RD12 but so far has only produced RD33 in one year. In Tamil Nadu, TNAU has not persuaded the State Extension Department to multiply PMK-3 or Anna R 4 seed for large-scale distribution. The state agriculture department multiplies major HYVs and supplies them through its extension network. Its main purpose is to contribute to consumer food security in the state. The rainfed rice districts of Tamil Nadu contribute relatively little towards meeting the state's food (rice) security needs. Hence, the department has shown no interest in multiplying DT varieties in large quantities to meet demands of the rainfed system. TNAU remains the only source of DT rice seeds and its ability to produce seed is limited. In Eastern India, seed production is a major bottleneck because the new State of Jharkhand does not have a functioning government seed production and distribution system. Seed production and distribution has been left to NGOs such as GVT and Catholic Relief Services. But GVT has limited resources. Its seed research and production efforts were initially supported by DFID and then by the Rockefeller Foundation but have not become self-supporting. Farmer-to-farmer spread seems to be the primary mode of dissemination in three states (Orissa, West Bengal, and Jharkhand) where drought tolerant rice varieties were introduced [13]. Currently RiU of DFID is funding the dissemination of Ashoka varieties under its South Asia initiative on "Best Bets" project. The seeds are disseminated through a newly formed farmers’ seed producing company (Jagan Nath Seed Producing Company, Baripada), which has been formed and registered in Mayurbhanj district of Orissa under RiU, which has become functional since mid 2010[23].

\section{Conclusions}

The farm-level surveys conducted by this paper's authors provide promising signs that plant breeders can develop DT cultivars that do not sacrifice yield or grain quality. In fact, most cultivars released so far actually increase yields in good years as well as protect farmers from low yields in moderate drought years. However, it is important to note that during serious droughts like those faced by farmers in eastern and southern India in 2009; even improved DT varieties cannot survive.

Despite promising performance in farmers' fields, these cultivars have not spread widely. Three reasons seem to account for their slow spread. The first is the characteristics of the new DT cultivars. These cultivars are better yielding and sometimes have better grain quality than current cultivars in good years, but average yields increases of between 5 and 10 percent may not be immediately obvious to farmers especially (when) in rainfed conditions where there is a lot of yield variability. The superiority in drought years will probably only be obvious during a moderate drought year, but we were not able to measure their superiority (in moderate drought) in farmers' fields because the first years of our surveys were mainly good years in our three focus countries, except for the severe drought in East India and South India in 2009. In East India, both the DT and non-DT rice were wiped out in 2009.

The second reason is that the regulatory procedures for approving drought tolerant varieties may not be in place, and when they are in place, it can take five to six years for approval. This can be expensive. The third reason for the slow spread is that both public and private sector seed producers have not been very interested in DT seed as a result of small market size for any individual variety[24] and hybrid seed production problems for hybrid rice in China. 
Farmers are just beginning to see and benefit from new biotechnology tools. The first varieties developed by molecular breeding have just been approved for cultivation in East India and Karnataka. They are the result of major investments in understanding how rice deals with drought and what gene combinations provide drought tolerance. This knowledge has been turned into molecular markers which could identify sources of DT varieties in near future. It will also become much easier to combine DT with visible traits that farmers want such as grain quality and high yield in normal years.

GM technology for drought tolerant rice is much further off. China is the only country that has approved any GM rice and that is for insect resistance. Even in China, farmers will not see this GM insect resistant technology for several more years. The problems of obtaining approval for GM food crops of any type have limited scientists' enthusiasm for GM research on rice in the public and private sectors.

Several developments suggest the drought tolerant traits developed by the Rockefeller Foundation program will spread more widely in the near future. The first development is the spread of rice research by the Asian private sector. In China, scientists are now being approached by large commercial seed companies about the possibility of producing the DT hybrids. In Tamil Nadu seed companies, such as Rasi, are using drought tolerant lines from Tamil Nadu Agricultural University in their hybrid rice breeding programs and a number of companies have expressed interest in getting access to the aerobic DT rice varieties being developed by the University of Agricultural Sciences in Bangalore. These companies are not going to sell DT hybrids to farmers who have upland plots in Jharkhand, but they will be pushing into some lowland areas which previously did not have hybrids or HYVs. In addition they will provide some farmers in China and India who now use hybrids with an extra measure of protection against crops losses.

The second important development was mentioned above-rapid development of techniques using genomics and molecular markers to develop new varieties. This is combined with the third development led by national governments, international agricultural research centers and foundations to increase investments in plant breeding using molecular markers and new programs to spread these varieties to the poor. Donor funded programs, like stress-tolerant rice for Africa and South Asia, are putting large amounts of money into submergence tolerance but they are also increasing the funding of drought tolerance and pest tolerance as well.

What can Asian governments and donors do to increase the development and spread of DT cultivars? First, they can make breeding lines with DT traits and molecular markers easily available to the private sector so that they can incorporate DT traits into their commercial hybrids, particularly for poor areas. Second, they can subsidize private sector production of DT seed or provide more government money for state extension services to produce DT varieties. Third, Asian government research programs need continued and increasing funding for research to develop the next generation of DT cultivars based on the new molecular markers and increasing knowledge about drought tolerance from genomics and systems biology that is now available to plant breeders. The efficiency of these programs can be encouraged by linking scientists to national and international networks, such as those developed by Rockefeller Foundation and the International Rice Research Institute.

Drought tolerant traits developed in national programs and at the International Rice Research Institute may well be applicable in Africa, but the experience of Asia with drought tolerance suggests Africans will have to make major investments in adaptive research to develop DT rice for their 
conditions. In addition, major government investments in seed production and distribution will also be required.

\section{References and Notes}

1. Pandey, S.; Pal, S. Are less-favored environments over-invested? The case of rice research in India. Food Policy 2007, 32, 606-623.

2. Kamoshita, A.; ChandraBabu, R; Boopathi, M.; Fukai, S. Phenotypic and genotypic analysis of drought-resistance traits for development of rice cultivars adapted to rainfed environments. Field Crops Res. 2008, 109, 1-23.

3. Marker assisted selection (MAS) refers to the use of DNA markers that are tightly-linked to target loci as a substitute for or to assist phenotypic screening. The method whereby phenotypic selection is based on DNA markers termed molecular breeding (MB) i.e., DNA markers are utilized for backcrossing for greater efficiency -marker assisted backcrossing (MAB) (Collard \& McKill, 2002).

4. O'Toole, J.C. Rice and Water: The Final Frontier. In Proceedings of the First International Conference on Rice for the Future, Bangkok, Thailand, 31 August-2 September 2004.

5. Kostandini, G.; Bradford, F.M.; Omamo, S.W.; Wood, S. Ex-ante analysis of the benefits of transgenic drought tolerance research on cereal crops in low-income countries. Agric. Econ. 2009, 40, 477-492.

6. Ramasamy, C.; Selvaraj, K.N.; Norton, G.W.; Vijayragahavan, V.K. Economic and Environmental Benefits and Costs of Transgenic Crops: An Ex-ante Assessment; Tamil Nadu Agricultural University Press: Coimbatore, India, 2007.

7. Toenniessen, G.H. Rice Biotechnology Capacity Building in Asia; Ives, C.L., Bedord, B.M., Eds.; CABI Publishing: Wallingford, UK, 1998; pp. 201-212.

8. O’Toole, J.C.; Toenniessen, G.H.; Murashige, T.; Harris, R.R.; Herdt, R.W. The rockefeller foundation's international program on rice biotechnology. Rice Genet. IV 2000, 4, 39-59.

9. These included the Generation Challenge Program of the CGIAR, the Department of Biotechnology of the Government of India, the Sir Ratan Tata Trust, and the Bill \& Melinda Gates Foundation.

10. Chandra Babu, R. Breeding for Drought Resistance in Rice: An Update from India. Presented at the workshop on Economic Impact of Rockefeller Funded Drought Tolerant Rice in Asia, Indian Statistical Institute, New Delhi, India, 19-20 November 2010.

11. This includes investments using biotech tools such as molecular assisted selection for varietal selection and using molecular breeding for developing cultivars resistant to biotic and abiotic stresses.

12. Though RD 33 was suitable to grow under drought conditions with fine grain quality attributes of Jasmine rice (a very fine, export grade rice), it was not promoted by the department of agriculture since its release in 2009. This might be due to the concerns raised by traditional exporters of Jasmine (merchants/farmer groups) due to potential contamination and thus would affect the price of Jasmine at the export market.

13. DFID-RIU. Report on New Upland Rice Varieties for India: Rainfed Agriculture Impact Study No.1. Research into Use (RIU) Programme, DFID, London, UK, 2010. 
14. Accessed the website at www.aerobicrice.com.

15. In Zhejiang, though the amount of water used for DT was lower ( 0.7 times) against 1.1 number of irrigation for NDT cultivars, it was not statistically significant in our total sample of farm households.

16. Zhang, S. Evaluating Rockefeller Foundation Research on Drought Tolerant Rice in China. MS Thesis, Department of Agricultural, Food and Resource Economics, Rutgers University, New Brunswick, NJ, USA, 2010.

17. Virk, S.D.; Witcombe, J.R. Trade-offs between on-farm varietal diversity and highly client-oriented breeding-A case study of upland rice in India. Genet. Resour. Crop Evol. 2007, 54, 823-835.

18. Grain self-sufficiency of a household is the period of time that households can feed themselves without buying from the market. It increased by 2 weeks to 1 month in Banswara district; and up to 2 months for farmers in Hazaribagh district, depending on the size of the land available.

19. Supplementary sources of irrigation are mainly available through tanks or farm ponds - which again depend on the availability of rainfall; less than $20 \%$ of the farms in these districts have tube wells or canal irrigation. The critical stages of rice crop growth includes flowering and before grain filling stage.

20. Selvaraj, K.N.; Suresh Kumar, S.; Sankar, M. Drought Impact and Adoption of Drought Tolerant Rice Varieties in Rainfed Rice Ecosystem of Tamil Nadu. Prepared for Rockefeller Foundation project progress report to Rutgers University, NJ, USA, 2010.

21. Shenggen, F.; Hazell, P.B.R. Should developing countries invest more in less-favored areas? An empirical analysis of rural India. Econ. Polit. Wkly 2000, 35, 1455-1464.

22. From our initial estimates, for TNAU DT rice research alone, RF has invested to the tune of US\$ 1 million over 10 years that includes training the scientists and establishing a research program.

23. The company is expected to produce $150 \mathrm{MT}$ of seeds of DT rice varieties (for both upland and transplanted conditions) in collaboration with University of Bangor and its Indian partners, which includes 50 MT of newly developed upland variety, PY 84(Personal communication with Dr. Prasad, GVT, Ranchi, December 2010).

24. The market for specific varieties is likely to be limited because different regions and seasons have different types of drought. So, no one DT variety is likely to spread in a very large region. In addition varieties by their nature have a limited market size because farmers can produce the new variety themselves.

(C) 2011 by the authors; licensee MDPI, Basel, Switzerland. This article is an open access article distributed under the terms and conditions of the Creative Commons Attribution license (http://creativecommons.org/licenses/by/3.0/). 